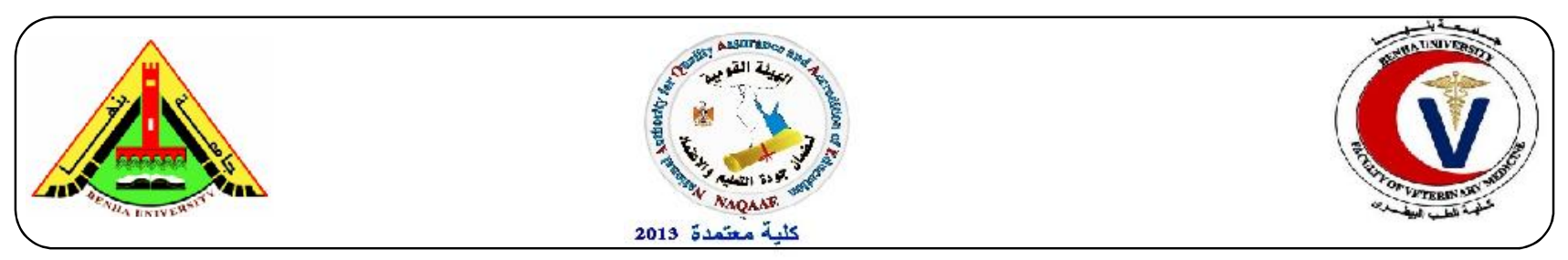

\title{
Heavy metal and trace element residues and health risk assessment in raw milk and dairy products with a trail for removal of copper residues
}

\author{
Mohamed A. H. Mansour ${ }^{1}$, Eman N. Abdelfatah ${ }^{1 *}$, Nagwa I. Ahmed ${ }^{2}$, Hussein H. El-Ganzory ${ }^{2}$ \\ ${ }^{1}$ Department of Food Control, Faculty of Veterinary Medicine, Zagazig University, Egypt.
}

${ }^{2}$ Animal Health Institute-Zagazig.

\section{A B S T R A C T}

This study was conducted to determine the residues of Lead $(\mathrm{Pb})$, Cadmium $(\mathrm{Cd})$, and Copper $(\mathrm{Cu})$ in raw milk of different species and dairy products, and to estimate the dietary intake of such metals, as well as to evaluate the potential health hazards of these metals to humans through consuming milk and dairy products. On the other hand, we made a trial to remove copper residues using adsorption properties of the resin. Therefore, a total of 120 random samples of milk and dairy products, including 80 samples of raw milk of different species from different dairy shops, and farms in Sharkia Governorate, Egypt, in addition to 20 samples for each of UHT milk and Kariesh cheese, were collected. $\mathrm{Pb}$ and $\mathrm{Cu}$ residues in the examined samples were ranged from 1.85-2.78, 0.009-0.81ppm, respectively, while $\mathrm{Cd}$ was detected only in raw goat's milk and kariesh cheese samples. However, it is worth to clear that $\mathrm{Pb}$ was recorded the highest levels in the examined samples, since most of samples were over the permissible level of $0.1 \mathrm{mg} / \mathrm{kg}$ established by Egyptian Standard. Human health risk associated with consuming milk and other examined dairy products was identified using Target Health Quotient (THQ) showed that $\mathrm{Pb}$ is the most dangerous element measured in these products as its value was more than one in $66.7 \%$ of samples. In the present study, performance of IMAC HP resin was assessed for the first time for removal of $\mathrm{Cu}$ ions from artificially contaminated raw cow's milk, although it is used extensively to purify water from heavy metals. It was noticed that the removal efficiency of $\mathrm{Cu}$ ions increased with higher resin concentration, and increasing time, as maximum removal percent $(76.89 \%$ ) was achieved by using $0.8 \mathrm{~g} / \mathrm{L}$. IMAC HP resin after 45 min. Finally, it was concluded that this type of resin is suitable for the adsorption of $\mathrm{Cu}$ ions from artificially contaminated raw milk.

Keywords: Heavy metals, Milk, Resin, Atomic absorption spectrophotometer.

(http://www.bvmj.bu.edu.eg) (BVMJ-36(1): 403-417, 2019)

\section{INTRODUCTION}

Heavy metals are widespread materials present in our nature and become easily accumulated in different food chains as they are nonbiodegradable (Aslam et al., 2011). Metal contents of milk and milk products can be classified into two groups, essential elements that are required but only at low doses as copper $(\mathrm{Cu})$, iron $(\mathrm{Fe})$, and zinc $(\mathrm{Zn})$. The second one is non-essential elements that have no biological role including arsenic (As), lead $(\mathrm{Pb})$, and cadmium (Cd) (Khan et al., 2013). 
These toxic metals are considered generally air pollutants which are produced and diffused into it mainly from various industrial activities (WHO, 2007), from which they are reached soil, plants, foods, and waters causing their contamination with these metals (Bilandzic et al., 2011). Therefore, they enter into the food chain easily, as dairy animals ingest them while grazing in the pasture from contaminated concentrate feeds, or even from water. Then, in the animal these metals are transferred to milk (Maas et al., 2011). Food considered the main route of exposure as it is representing about $90 \%$ of the total intake (WHO, 2007). In milk and different milk products, presence of $\mathrm{Pb}$ and $\mathrm{Cd}$ residues is of specific interest, as their presence even in low amounts, $\mathrm{Pb}$ to poisoning and other great disorders in the body (Ghorbel-Abid et al., 2010). Also, they are considered potential carcinogens (Zhuang et al., 2009).

On the other hand, $\mathrm{Cu}$ is one of the essential micronutrients for normal function of our body, as it is required for the absorption of iron and as cofactor of some enzymes that are essential for different vital processes in the body (Solaiman et al., 2001). However its intake in higher amounts above the safe levels recommended by the international organizations may cause hazardous effects to the human health and this is mainly occur due to presence of $\mathrm{Cu}$ with high levels in animal feed (Licata et al., 2012).

Therefore, it is necessary to examine milk and its products for the presence of the residual concentrations of different metals and assessed their potential health hazards to ensure consumer health. For this purpose, determining the dietary intake of each metal and comparing it with the permissible limits set by regulatory agencies is important (Leblanc et al., 2000). Moreover, the target hazard quotient (THQ) is one of the approaches that had been recommended for evaluating the potential health hazards of intake of various pollutants on human (US EPA, 2000).

Additionally, there are many techniques have been developed for metals removal such as chemical treatment, flocculation, coagulation, membrane separation, filtration and adsorption (Geise et al., 2010, Yargeau and Zeman, 2012, Gupta et al., 2013 and Madsen, 2014). Adsorption is one of these methods that has some advantages, including simple design, low cost, and absence of sludge formation. Many natural and synthetic materials have been used to remove heavy metals in this technique, including clay, seaweed and biomass, activated carbon, and mesoporous silica (Chen et al., 2010). Resin is a novel chelating ion exchange used for removal of heavy metals by the adsorption method depending on their high selectivity in binding metal ions as reported by many studies (Dinu and Dragan, 2008, Alyüz and Veli, 2009 and Lasheen et al., 2017).

Therefore, the major aim of this study was to determine the contamination levels of $\mathrm{Pb}, \mathrm{Cd}$, $\mathrm{Cu}$, in different types of raw milk and milk products and to assess their potential health hazards for human using target health quotients (THQ). Finally, the removal of $\mathrm{Cu}$ from artificially contaminated raw milk by using the adsorption properties of a suitable chelating ion exchange (CIE) resin was investigated.

\section{Materials and methods}

\subsection{Collection of samples}

A total of 120 random samples of milk and milk products, including 80 samples of raw milk of different species (sheep, goat, cow, buffalo, 20 samples for each) from different dairy shops, and farms in Diarb Negm and Zagazig, Sharkia Governorate, in addition to 20 samples for each of Ultra heat treated (UHT) milk and Kariesh cheese, were collected in clean polyethylene bags and in its original container from different farmers, dairy 
shops, and supermarkets. Each sample was labelled to identify the source, site and date of sampling. The samples transported to the laboratory without delay in an ice box and stored at $-2^{\circ} \mathrm{C}$ until analysis.

\subsection{Preparation and analysis of the collected samples}

Each prepared sample was digested according to (Tsoumbaris and Papadopoulou, 1994) until obtained a clear solution. Samples were filtered and diluted to $25 \mathrm{ml}$ with deionized water and filtered through whatman filter paper No. 42. All filtrated samples were analyzed for presence $\mathrm{Pb}, \mathrm{Cu}$, and $\mathrm{Cd}$ by using Buck Scientific Atomic Absorption Spectrophotometry (AAS) model 210VGP at wavelengths of $217,228.8,324.8, \mathrm{~nm}$ respectively. It was applied at the Atomic Absorption Unit of the Central Laboratory in the Faculty of Veterinary Medicine, Zagazig University. Three replicates were done, and the result was the average of these replicates.

\subsection{Calculations}

\subsubsection{Calculation of Estimated daily intake of metals (mg/kg.bw/day) (EDI)}

The daily intake of the examined heavy metals for an adult person (60 $\mathrm{kg} \mathrm{BW})$ from consumption of milk and cheese was calculated according to The Nutrition Institute, Cairo, (2007). Where the average daily consumption was considered to be $200 \mathrm{~mL}$, and $45 \mathrm{gm}$ of milk, and kareish cheese, respectively. Depending on the mean concentration of metal in food, the daily food consumption, and the body weight of the adult human.

\subsubsection{Target hazard quotient (THQ)}

The THQ for the consumers via consumption of polluted milk and cheese was evaluated depending on the determined dose and the reference oral dose (RFDO) for pollutant. When the THQ is less than one, it assumed that the inhabitant did not expose to adverse effects. The severity of health hazards is enhanced with increasing its value more than one (Zhuang et al., 2009).

\subsection{Treatment process for metal removal from experimentally contaminated raw cow's milk}

\subsubsection{Materials}

1- IMAC HB 333: weak acid cation exchange resin containing carboxyl group on an acrylic matrix according to (Nasef et al., 2002).

2- A standard solution of copper sulfate (tested metal).

3- $\mathrm{PH}$ adjustments were carried out by using $0.1 \mathrm{~N} \mathrm{HCl}$ and $0.1 \mathrm{~N} \mathrm{NaOH}$.

\subsubsection{Apparatus:}

1- Atomic Absorption Spectrophotometry (AAS) model 210VGP at wavelengths of 228.8 $\mathrm{nm}$

2-PH meter (Adwa kft, AD11, Romania)

\section{3-Electric Shaker (SCILOGEX, MX-S)}

\subsubsection{Procedures:}

The ion exchange experiments were performed, using different resin doses and contact periods during agitation at room temperature. The effect of each parameter was determined, while other parameters were kept constant. 3 liters of raw cow's milk were collected from a dairy farm at El-Sharkia Governorate, and immediately taken to the laboratory. At first, only $20 \mathrm{ml}$ was taken from one liter for heavy metal analysis and determination of copper and calcium in raw milk without any addition. Then, $100 \mathrm{ml}$ of synthetic solution of copper sulfate $(100 \mathrm{mg} / \mathrm{L})$ was added into the second flask contained another liter of raw milk (Alyüz and Veli, 2009), from which 4 equal volumes $(100 \mathrm{ml}$ each) were transferred into clean and acid washed flasks. To each volume, IMAC HB 333 was added with different amounts $0.05,0.2$, 0.4 , and $0.8 \mathrm{~g}$. PH adjusted at 6 by using $0.1 \mathrm{~N}$ sodium hydroxide and $0.1 \mathrm{~N}$ hydrochloric acid. Solutions were shaken continuously by using electric shaker at $200 \mathrm{rpm}$ for $60 \mathrm{~min}$. The milk of each volume was strained through several layers of cleaned gauze into another acid cleaned flask, for preventing the passage of 
resin beads. From each treated milk $10 \mathrm{ml}$ subsample were taken and analyzed for metal content by spectrophotometer as mentioned above. The results were recorded.

The 3rd liter of raw milk was also experimentally contaminated with $100 \mathrm{ml}$ Copper sulfate of $(100 \mathrm{mg} / \mathrm{L})$ and added IMAC HB 333 with a constant concentration that give the highest removal percentage in the previous part of the experiment. Then, samples were taken at various durations of agitation $(5,15$, 30, $45 \mathrm{~min}$.) and metal residues were analyzed. The results were recorded.

\subsection{Statistical analysis}

All the data analysed and Comparisons among means of different groups for each element were performed using ANOVA test using SPSS/PCT (Foster, 2001).

\section{RESULTS}

From the data shown in (table, 1), it is apparent that the average concentrations of $\mathrm{Pb}$ were $2.68,2.04,2.78,1.85,1.94$ and $2.26 \mathrm{ppm}$ in raw cow's, buffalo's, sheep's, goat's milk, UHT milk, and kariesh cheese, respectively, there was no observed significant difference between samples.

While Cd failed to be detected in all samples except raw goat's milk, and kariesh cheese without observed significant difference between samples which were $(0.02 \pm 0.005)$, $(0.02 \pm 0.016)$ respectively. Concerning $\mathrm{Cu}$ residues, the highest mean values of $\mathrm{Cu}$ in our work was found in Kariesh cheese samples $(0.81 \pm 0.09 \mathrm{ppm})$, while the lowest value was found in raw cow's milk samples $(0.009 \pm 0.008$ ppm).

There was no significant difference between UHT, kariesh cheese, goat milk means values for $\mathrm{Cu}$ at $\mathrm{p}<0.05$. While the mean value of $\mathrm{Cu}$ in UHT milk was significantly higher than those of sheep's and buffalo's milk. In addition, the mean value of sheep's milk was significantly higher than that in cow milk.
On the other hand, the levels of $\mathrm{Pb}$ in the examined milk and cheese samples were very high and exceeded the permissible level of 0.1 $\mathrm{mg} / \mathrm{kg}$ established by Egyptian Standard, (2012) table (2).

Table (2) showed that, only 5\% of raw goat's milk samples recorded $\mathrm{Cd}$ content higher than the PL $(0.05 \mathrm{ppm})$ according to Egyptian Standard, (2012). The permissible limit of $\mathrm{Cu}$ was $0.4 \mathrm{ppm}$ according to Anonymous, (1998), where 65\% buffalo's milk, $75 \%$ sheep's milk, $65 \%$ goat's milk, $75 \%$ of UHT milk, and 80\% kariesh cheese exceeded the permissible limit, while no samples of cow's milk exceed the permissible limit.

The accepted daily intake (ADI) of $\mathrm{Pb}, \mathrm{Cd}$, and $\mathrm{Cu}$ in all examined samples and their calculated daily intake resulted from consumption of $200 \mathrm{ml}$ of raw milk and UHT milk or $45 \mathrm{~g}$ kariesh cheese per day were illustrated in table (3). Where the highest calculated daily intake for $\mathrm{Pb}$ was 0.556 $\mathrm{mg} /$ day/person from consumption of raw sheep's milk, while the least estimated value for it recorded $0.102 \mathrm{mg} /$ day/person from consumption of kariesh cheese which represent about $111.2 \%, 20.4 \%$ of ADI recommended by Codex Alimentarius Commission, (2014) respectively.

Table (3) showed that the average concentration of $\mathrm{Cd}$ in the examined raw goat's milk, and kariesh cheese samples was 0.02, $0.02 \mathrm{ppm}$ for each type respectively that gave daily intake of about 0.004, $0.0009 \mathrm{mg}$ /day/person from consumption of $200 \mathrm{ml}$ of raw goat's milk, and $45 \mathrm{gm}$ of kariesh cheese that contributed about $5.71 \%, 1.29 \%$ of ADI recommended by Codex Alimentarius Commission, (2014). Concerning daily intake of $\mathrm{Cu}$, it could be concluded that the average daily intake of $\mathrm{Cu}$ from consumption of different examined samples were relatively low as was shown in table (3) and represents a 
low percentage of ADI recommended by FDA, (2013). Also, our results showed that milk and dairy products cannot contribute a great amount of the supply of $\mathrm{Cu}$ in the human diet.

As shown in table (4) THQ values of $(\mathrm{Pb})>1$ in raw cow's, buffalo's, sheep's, goat's milk, and UHT milk, while it was $<1$ in kariesh cheese. Regarding THQ values of $\mathrm{Cd}$, they were $<1$ through the consumption of all the examined samples. On the other hand, THQ values of $\mathrm{Cu}$ were less than one through the consumption of all the examined samples.
Concerning the experimental part results which were represented in the figures (1.2). It was cleared that the adsorption percentage of $\mathrm{Cu}$ ions increased with increasing the resin concentration as the removal efficiency was $27.7 \%$ by using $0.05 \mathrm{~g} / \mathrm{L}$. resin dose, while it was $76.89 \%$ by using $0.8 \mathrm{~g} / \mathrm{L}$ of it Figure (1A). There were no changes detected in the $\mathrm{Ca}$ content of the examined raw cow's milk samples with different resin concentration. Figure 1B, cleared that $\mathrm{Cu}$ ions adsorption increased with increasing the contact time with resin molecules till reach the maximum at the end of time (45 min.).

Table 1. Statistical analytical results of the examined residues of $\mathrm{Pb}, \mathrm{Cd}$ and $\mathrm{Cu}$ in different raw milk and dairy product samples $($ No. $=20)$.

\begin{tabular}{|c|c|c|c|c|c|c|c|}
\hline \multicolumn{2}{|c|}{$\begin{array}{c}\text { Samples } \\
\text { Metal }\end{array}$} & $\begin{array}{l}\text { Raw Cow's } \\
\text { milk }\end{array}$ & $\begin{array}{c}\text { Raw } \\
\text { buffaloe's } \\
\text { milk }\end{array}$ & $\begin{array}{l}\text { Raw sheep's } \\
\text { milk }\end{array}$ & $\begin{array}{c}\text { Raw goat's } \\
\text { milk }\end{array}$ & UHT milk & $\begin{array}{l}\text { Kariesh } \\
\text { cheese }\end{array}$ \\
\hline \multirow{5}{*}{$\begin{array}{c}\mathrm{Pb} \\
(\mathrm{ppm})\end{array}$} & No. & 20 & 19 & 20 & 20 & 20 & 18 \\
\hline & $\%$ & $100 \%$ & $95 \%$ & $100 \%$ & $100 \%$ & $100 \%$ & $90 \%$ \\
\hline & Min. & 0.21 & 0.12 & 0.59 & 0.06 & 0.03 & 0.33 \\
\hline & Max & 6.32 & 4.69 & 5.90 & 4.21 & 3.64 & 4.17 \\
\hline & Mean \pm SE & $2.68 \pm 0.41^{\mathrm{a}}$ & $2.04 \pm 0.34^{\mathrm{a}}$ & $2.78 \pm 0.35^{\mathrm{a}}$ & $1.85 \pm 0.29^{\mathrm{a}}$ & $1.94 \pm 0.26^{\mathrm{a}}$ & $2.26 \pm 0.35^{\mathrm{a}}$ \\
\hline \multirow{5}{*}{$\begin{array}{c}\mathrm{Cd} \\
(\mathrm{ppm})\end{array}$} & No. & 0 & 0 & 0 & 7 & 0 & 7 \\
\hline & $\%$ & $0 \%$ & $0 \%$ & $0 \%$ & $35 \%$ & $0 \%$ & $35 \%$ \\
\hline & Min. & 0.00 & 0.00 & 0.00 & 0.01 & 0.00 & 0.01 \\
\hline & Max & 0.00 & 0.00 & 0.00 & 3.64 & 0.00 & 4.21 \\
\hline & Mean \pm SE & 0.00 & 0.00 & 0.00 & $0.02 \pm 0.005^{\mathrm{d}}$ & 0.00 & $0.02 \pm 0.016^{\mathrm{d}}$ \\
\hline \multirow{5}{*}{$\begin{array}{c}\mathrm{Cu} \\
(\mathrm{ppm})\end{array}$} & No. & 1 & 20 & 20 & 20 & 20 & 20 \\
\hline & $\%$ & $5 \%$ & $100 \%$ & $100 \%$ & $100 \%$ & $100 \%$ & $100 \%$ \\
\hline & Min. & 0.00 & 0.07 & 0.10 & 0.29 & 0.02 & 0.05 \\
\hline & Max & 0.18 & 1.46 & 0.77 & 1.48 & 1.21 & 1.78 \\
\hline & Mean \pm SE & $0.009 \pm 0.008^{\mathrm{d}}$ & $0.58 \pm 0.07^{\mathrm{bc}}$ & $0.49 \pm 0.05^{\mathrm{c}}$ & $0.77 \pm 0.08^{\mathrm{ab}}$ & $0.62 \pm 0.08^{\mathrm{abc}}$ & $0.81 \pm 0.09^{\mathrm{a}}$ \\
\hline
\end{tabular}


Table 2. Frequency distribution of $\mathrm{Pb}, \mathrm{Cd}$, and $\mathrm{Cu}$ in the examined different raw milk and dairy product samples $($ No. $=20)$.

\begin{tabular}{|c|c|c|c|c|c|c|c|c|c|c|c|c|c|}
\hline \multirow[t]{3}{*}{ Metal } & \multirow{3}{*}{$\begin{array}{c}\text { P.L. } \\
\text { (ppm) }\end{array}$} & \multicolumn{12}{|c|}{ Milk samples that exceed the permissible limit (P.L.) } \\
\hline & & \multicolumn{2}{|c|}{$\begin{array}{l}\text { Cow's } \\
\text { milk }\end{array}$} & \multicolumn{2}{|c|}{$\begin{array}{l}\text { Buffalo's } \\
\text { Milk }\end{array}$} & \multicolumn{2}{|c|}{$\begin{array}{l}\text { Sheep's } \\
\text { Milk }\end{array}$} & \multicolumn{2}{|c|}{$\begin{array}{l}\text { Goat's } \\
\text { milk }\end{array}$} & \multicolumn{2}{|c|}{$\begin{array}{l}\text { UHT } \\
\text { Milk }\end{array}$} & \multicolumn{2}{|c|}{$\begin{array}{l}\text { Kariesh } \\
\text { cheese }\end{array}$} \\
\hline & & No. & $\%$ & No. & $\%$ & No. & $\%$ & No. & $\%$ & No. & $\%$ & No. & $\%$ \\
\hline $\mathrm{Pb}$ & $0.1^{\mathrm{a}}$ & 20 & $\begin{array}{c}100 \\
\%\end{array}$ & 18 & $90 \%$ & 20 & $100 \%$ & 19 & $90 \%$ & 18 & $90 \%$ & 20 & $100 \%$ \\
\hline $\mathrm{Cd}$ & $0.05^{\mathrm{a}}$ & 0 & $0 \%$ & 0 & $0 \%$ & 0 & $0 \%$ & 1 & $5 \%$ & 0 & $0 \%$ & 0 & $0 \%$ \\
\hline $\mathrm{Cu}$ & $0.4^{\mathrm{b}}$ & 0 & $0 \%$ & 13 & $65 \%$ & 15 & $75 \%$ & 13 & $65 \%$ & 15 & $75 \%$ & 16 & $80 \%$ \\
\hline
\end{tabular}

Table 3. Comparison of Acceptable Daily Intake (ADI) values of $\mathrm{Pb}, \mathrm{Cd}$, and $\mathrm{Cu}$ with the calculated daily intake of the examined samples for adult ( $\mathrm{mg} /$ day/person).

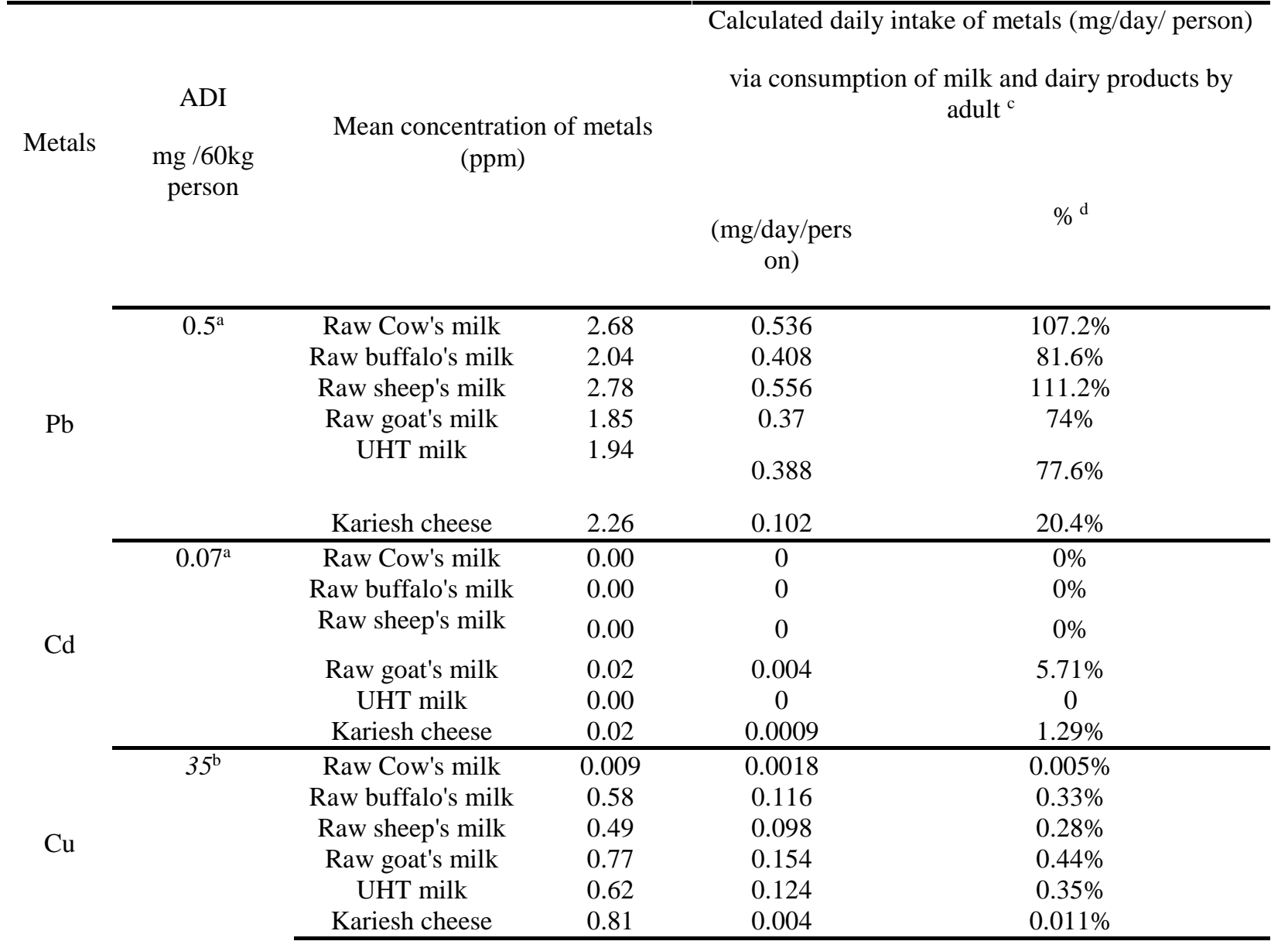

a: Codex Alimentarius Commission (2014).

b: FDA, (2013).

c: Daily consumption for adult person (60 kg b.w.) according to Nutrition Institute, Cairo, 2007.

D: Percentage calculated to ADI. 
Table 4. Target hazard quotient (THQ) for daily exposure to $\mathrm{Pb}, \mathrm{Cd}$, and $\mathrm{Cu}$ through consumption of different raw milk and dairy product samples.

\begin{tabular}{ccccccc}
\hline & \multicolumn{2}{c}{$\mathrm{Pb}$} & \multicolumn{2}{c}{$\mathrm{Cd}$} & \multicolumn{2}{c}{$\mathrm{Cu}$} \\
\cline { 2 - 7 } & $\mathrm{EDI}(\mathrm{mg} / \mathrm{kg}$ bw/day) & $\begin{array}{c}\mathrm{TH} \\
\mathrm{Q}\end{array}$ & $\begin{array}{c}\mathrm{EDI}(\mathrm{mg} / \mathrm{kg} \\
\text { bw/day })\end{array}$ & $\mathrm{THQ}$ & $\begin{array}{c}\mathrm{EDI}(\mathrm{mg} / \mathrm{kg} \\
\text { bw/day) }\end{array}$ & THQ \\
\hline $\begin{array}{c}\text { Raw Cow's } \\
\text { milk }\end{array}$ & 0.009 & 2.57 & 0 & 0 & 0.00003 & 0.000 \\
\hline $\begin{array}{c}\text { Raw buffalo's } \\
\text { milk }\end{array}$ & 0.007 & 2 & 0 & 0 & 0.002 & 0.05 \\
\hline $\begin{array}{c}\text { Raw sheep's } \\
\text { milk }\end{array}$ & 0.009 & 2.57 & 0 & 0 & 0.002 & 0.05 \\
\hline Raw goat's milk & 0.006 & 1.71 & 0.00007 & 0.07 & 0.003 & 0.075 \\
\hline UHT milk & 0.006 & 1.71 & 0 & 0 & 0.002 & 0.05 \\
\hline Kariesh Cheese & 0.002 & 0.57 & 0.00002 & 0.02 & 0.0006 & 0.015
\end{tabular}

$\mathrm{EDI}=$ Estimated daily intake $(\mathrm{mg} / \mathrm{kg}$ bw/day)

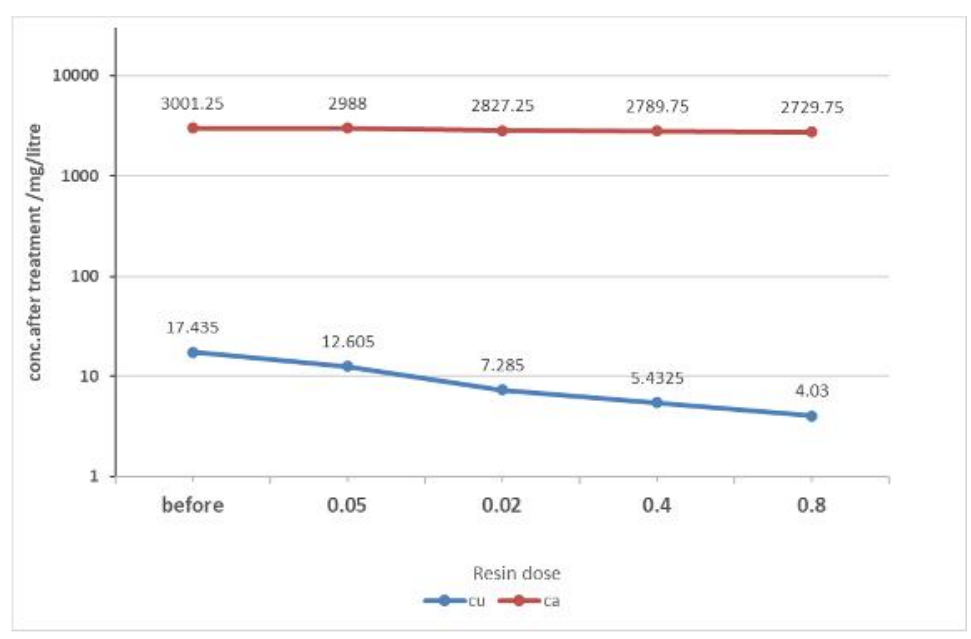

Fig.1A: Effectiveness of cation exchange with different concentration of resin on copper and calcium from fresh raw cow's milk.

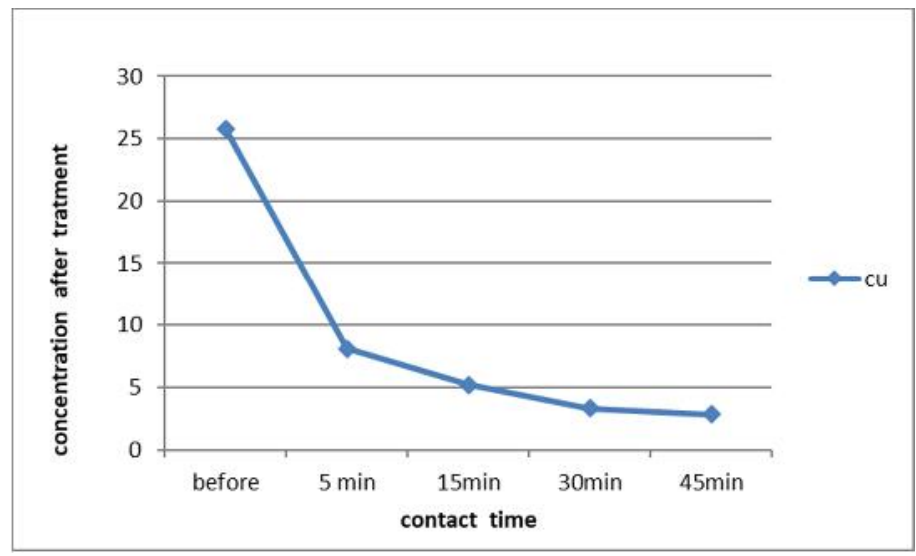

Fig.1B: Effectiveness of cation exchange of resin on copper from fresh raw cow's milk at different contact time. 


\section{DISCUSSION}

Milk and other milk products are considered the most important components of the daily diet, especially for sensitive groups including, infants, children, and old age (Giri et al., 2011). Thus, the high exposure of these products to heavy metals has a negative effect on human health (Khan et al., 2013).

Lead is one of the nonessential elements that have a severe toxic cumulative effect.

The environmental sources are as disposal of wastes, atmospheric deposition, urban effluent, and vehicle exhausts may be considered the major resources for the presence of $\mathrm{Pb}$ in milk and milk products (Meshref et al., 2014). Pb could release into the air in the form of metal fumes or suspended particles (Ihedioha and Okoye, 2012). It is worth mentioning that $\mathrm{Pb}$ is a probable human teratogen, associated with hypertension and cardiovascular disease, causing neurotoxicity and affect the male fertility, memory deterioration (El-Sokkary et al., 2003).

Several authors have conducted researches on $\mathrm{Pb}$, where lower results for milk samples were detected in different countries (Malhat et al., 2012, Temiz and Soylu, 2012, Rahimi, 2013, Ismail et al., 2015, Kim et al., 2016, and Castro-Gonzalez et al., 2017). For kariesh cheese, lower results were detected by (Ibrahim, 2004, Al-Ashmawy et al., 2008 and Deeb, 2010).

The higher levels of $\mathrm{pb}$ in the examined samples may be as a result of using contaminated water or sewerage water for agriculture purposes that may be directly accessed through drinking water, or through bioaccumulation of these metal residues in soil, fodder, and vegetables (Javed et al., 2009). Higher amount in kariesh cheese may be present because of the affinity of metals for the casein fraction, and also it was sold without a package (Fischer et al., 2011).

It is evident from the findings in Table (2) that mean concentrations of $\mathrm{Pb}$ in nearly all of samples were higher than standards set by the Egyptian Standard, (2012). Lower percentages were recorded by (El-Ansary, 2017 and Babu et al., 2018). These values can vary due to the sampling area and the time of year (Rahimi, 2013).

$\mathrm{Cd}$ is a toxic metal with extremely long biological half lifetime. Once contaminated food ingested, it can be absorbed via the alimentary tract, and may remain inside the body 15-20 years. It has many hazards on human health (Zhuang et al., 2009), such as renal damages, bone fractures, kidney dysfunction, and even cancer (Khan et al., 2013).

Concerning $\mathrm{Cd}$ results in our work, the results cleared the presence of $\mathrm{Cd}$ only in raw goat's milk and kariesh cheese, Cabrera et al. (1995) indicated that presence of low residues of $\mathrm{Cd}$ in raw or UHT milk and other milk products, except if dairy animals consumed polluted feed and water. Furthermore, $\mathrm{Cd}$ can be leached from food packages, or entered milk and other milk products during marketing, and storage. On the contrary, higher levels of $\mathrm{Cd}$ residues in raw milk and kariesh cheese were detected by (Javid et al., 2009, Deeb, 2010, Abd-El Aal et al., 2012, and Malhat et al., 2012).

Table (2) cleared that the mean concentrations of $\mathrm{Cd}$ only in $5 \%$ of raw goat's milk were higher than standards set by the EOSQ, (2012). Higher percentage was recorded by (El-Ansary, 2017 and Babu et al., 2018).

$\mathrm{Cu}$ is an essential microelement, necessary for adequate growth as it is responsible for many nutritional and biological functions in the body (Kazi et al., 2009). It is required only at low levels and if present in higher amounts, they can have some health hazards, and dairy technology problems (Lante et al., 2006).

The results in this work cleared that the concentration of $\mathrm{Cu}$ in different samples varied from 0.009 to $0.81 \mathrm{ppm}$. Lower results were 
detected by (Dobrzanski et al., 2005, Meshref et al., 2014, and Ahmad et al., 2017), while other authors recorded higher levels of $\mathrm{Cu}$ in cow milk samples (Yuet al., 2015, Issa et al., 2016 and Kabir et al., 2017) Regarding kareish cheese, higher level of $\mathrm{Cu}$ was reported by (Deeb, 2010). The presence of $\mathrm{Cu}$ residues in milk can occur from different sources as animal feed, water with high $\mathrm{Cu}$ content, or from $\mathrm{Cu}$ bearing and $\mathrm{Cu}$ alloys used in equipment (Mitchell, 1981).

Table (2) cleared that only raw cow's milk samples have no samples exceeded the standards for $\mathrm{Cu}$ according to Anonymous, (1998), while other samples exceeded it with different percentages varied from $65-80 \%$. Nearly similar percentages were detected by (Babu et al., 218), while higher percentage were recorded by (Ismail et al., 2017). Other author detected lower results (Puls, 1994).

Regarding the results in Table (3), it was cleared that, $\mathrm{Pb}$ had the highest calculated daily intake from consumption of $200 \mathrm{ml}$ raw sheep's milk per day (111.2\%), while $\mathrm{Cu}$ had the least calculated value $(0.005 \%)$ from consumption of $200 \mathrm{ml}$ raw cow's milk per day. According to these results, milk could be represent a danger for human health because of the amount of $\mathrm{Pb}$ found in the examined samples, as these content exceeded the permissible values set by the Egyptian Standard, (2012), and also because of the high amount of milk consumed daily (CastroGonzález et al., 2017), On the contrary, in relation to the cheeses, it may represent no danger for human health, because of the low amount of cheese consumed daily (MorenoRojas et al., 2010).

The THQ has been identified as a complex guideline used for evaluation of risks caused by permenant exposure to various pollutant. It is not a quantitative measure about the probability of exposing population to health risks, but it only indicates the risk level due to exposure (US EPA, 2000).
The THQ is a ratio of determined dose of a pollutant to a reference oral dose (RFDO) for that substance. The RFDO for $\mathrm{Pb}$, is 0.0035 $\mathrm{mg} / \mathrm{kg}$ bw/day according to US EPA, (2008), and for $\mathrm{Cd}$, and $\mathrm{Cu}$ are $0.001,0.04 \mathrm{mg} / \mathrm{kg}$ bw/day respectively according to USEPA, (2014).

According to the results of the present study, the consumers in Sharkia Governorate will be exposed to a potential health hazard from consuming these products because of the presence of $\mathrm{Pb}$ residues, as THQ values of $(\mathrm{Pb})$ $>1$ through the consumption of in in all examined samples except, kariesh cheese. While THQ values for $\mathrm{Cd}$, and $\mathrm{Cu}$ did not exceed any of the examined samples. These results were in agreement with those detected by (Meshref et al., 2014 and Ghafari and Sobhanardakani, 2017). Other authors found that none of the THQ values of $\mathrm{Cd}, \mathrm{Pb}$, and $\mathrm{Cu}$ were $>1$ through consumption of milk and dairy products (Arafa et al., 2014, and Kabir et al., 2017).

Ion exchange may be defined as the exchange of ions between the substrate and surrounding medium. Synthetic ion exchangers are generally polymeric materials that have been chemically treated to render them insoluble and to show the capacity of ion exchange, therefore these materials are used widely today (James and Medougall, 1996). Generally, resins are stable spherical, which resist physical degradation, high temperatures, and a wide $\mathrm{pH}$ range. They are completely insoluble in most aqueous and organic solutions (Sherrington, 1998). One of these resins is IMAC HP333, which is a weak acid cation exchange resin containing carboxylic groups on an acrylic matrix. It is designed for removing heavy metals from tap water for use in cooking and to improve the taste of water.

There are some parameters affect the quantitative uptake of metal ion by resin, including resin amount, $\mathrm{pH}$, initial metal concentration and contact time. The amount of 
$\mathrm{Cu}$ adsorption on resin was evaluated by using various concentration of IMAC HP resin $(0.05-0.8 \mathrm{~g})$, while the other parameters remained constant. It was apparent in (Figure, 1A) that the adsorption percentage of $\mathrm{Cu}$ ions increased with higher resin concentration and the removal efficiency of $76.89 \%$ was achieved by using $0.8 \mathrm{~g} / \mathrm{L}$. IMAC HP resin dose, and we used it as the optimum amount for the second part of the experiment. It can be explained as a result of availability of more adsorption sites and high surface area with increasing adsorbent dose. On the other hand, there is no noticeable change in $\mathrm{Ca}$ ion concentration using different amount of resin. Similar result was detected by (Nasef et al., 2002) as they concluded high removal percent for both $\mathrm{Cd}$ and $\mathrm{Pb}$ from fresh milk using 3\% resin. While (Feng et al., 1995) found that only 11 to $19 \%$ of the Fe could be removed from milk.

In the contrary Lasheen et al. (2017) found that increasing the adsorbent dose above 0.5 $\mathrm{g} / \mathrm{L}$ have a little or no change on metals removal, and explained this as a result of the aggregation on the adsorption sites, and so decreasing the surface area of the composite. We used low $\mathrm{pH}$ values (6) in our work, as $\mathrm{Cu}$ ions could not be adsorbed easily at low $\mathrm{pH}<$ 3 . The ions adsorption increased gradually with increasing $\mathrm{pH}$ till reaching 6 , while at higher $\mathrm{pH} \mathrm{Cu}$ ions precipitate due to formation of $\mathrm{Cu}$ hydroxides (Dinu and Dragan, 2008).

For analyzing effects of contact time during agitation on removal of $\mathrm{Cu}$ ions, using $0.8 \mathrm{~g} / \mathrm{L}$ resin at metal concentration of 100 $\mathrm{mg} / \mathrm{L}$ and $\mathrm{pH}$ (6). Results in (Figure, 1B) showed that the removal efficiency of metal ions was increased with increasing time and the highest percentage of $\mathrm{Cu}$ ions adsorption was reached after $45 \mathrm{~min}$. Similar results were recorded by (Pehlivan and Altun, 2006 and Alyüz and Veli, 2009 ) from using synthetic resin, but on aqueous solution.

\section{Conclusion}

It could be concluded that this survey confirmed the contamination of different types of raw milk and milk products with heavy metals.

\section{REFERENCES}

Ahmad, I., Zaman, A., Samad, N., Ayaz, M.M., Rukh, S.; Akbar, A. and Ullah, N. 2017. AtomicAbsorption Spectrophotometery Detection of Heavy Metals in Milk of Camel, Cattle, Buffalo and Goat from Various Areas of Khyber- Pakhtunkhwa (KPK). Pakistan. Journal of Analytical Bioanalytical Techniques, 8(3): 1-6.

Al-Ashmawy, M.A.M., Hassan, G.M. and Abd-Elall, A.A. 2008. Toxic heavy metals in market raw milk and some dairy products. Journal of Egyptian Veterinary Medicine Association, 68(2): 211-224.

Alyüz, B. and Veli, S. 2009. Kinetics and equilibrium studies for the removal of nickel and zinc from aqueous solutions by ion exchange resins. Journal of Hazardous Materials, 167(2009): 482488.

Anonymous, 1998. General standard for contaminants and toxins in foods. Maximum levels for contaminants and toxins in foods. Finland, Decision No. 169/93 given by Ministry of Trade and Industry, 4.

Arafa, M.S.; Walaa, A.M. and Hassan, N.Y. 2014. Heavy metals and trace elements levels in milk and milk products. Journal of Food Measurement, 8(4): 381-388.

Aslam, B.; Jved, I.; Hussain, K.F. and UrRahman, Z. 2011Uptake of heavy metal residues from sewerage sludge in the milk of goat and cattle during summer 
season. Journal of Pakistan Veterinary Journal, 31(1): 75-77.

Babu, A.J., Supriya, R.A., Swetha, C.S., Suganya, G., Reddy,G. V., Sasikala, V., Surendra, R. and Sreenivas, K.Y. 2018. Estimation of chromium, copper and lead in milk by inductively coupled plasma-optical emission spectrometry in Tirupati, Andhra Pradesh. The Pharma Innovation Journal, 7(8): 90-93.

Cabrera, C., Lorenzo, M.L. and Lopez, M.C. 1995. Lead and cadmium contamination in dairy products and its repercussion on total dietary intake. Journal of Agricultural and Food Chemistry, 43(6): 1605-1609.

Castro-González, N.P., Moreno-Rojas, R., Calderón Sánchez, F., Moreno Ortega, A., Juarez Meneses, M. 2017. Assessment risk to children's health due to consumption of cow's milk in polluted areas in Puebla and Tlaxcala, Mexico. Journal of Food Additives and Contaminants: Part B, 10(3): 200-207.

Chen, Y., Pan, B., Li, H., Zhang, W., Lv, L. and $\mathrm{Wu}$, J. 2010. Selective removal of $\mathrm{Cu}$ (II) ions by using cation-exchange resin-supported polyethyleneimine (PEI) nanoclusters. Journal of Environmental Science and Technology, 44(9): 3508-3513.

Codex Alimentarius Commission 2014. Joint FAO/WHO food standards programme contaminants in foods, Eighth Session, The Hague, The in foods, Eighth Session, The Hague, The Netherlands, 31 March - 4 April.

Deeb, A.M.M. 2010. Trace metals concentrations in cheese collected from Kafr El-Sheikh Governorate, Egypt.
Journal of Assiut Veterinary Medicine, 56(127): 75-84.

Dinu, M.V. and Dragan, E.S. 2008. Heavy metals adsorption on some iminodiacetate chelating resins as a function of the adsorption parameters. Journal of Reactive \& Functional Polymers, 68(2008): 1346-1354.

Dobrzanski, Z., Kolacz, R., Gorecka, H., Chojnacka, K. and Bartkowiak, A. 2005. The content of microelements and trace elements in raw milk from cows in the Silesian region. Pol. Journal of Environmental Studies, 14(5): 685-689.

El-Ansary, M.A. 2017. Determination of Heavy Metals Content (Cadmium and Lead) in Raw Cow's and Buffalo's Milk. International Journal of Current Research in Biosciences and Plant Biology, 4(8): 116-120.

El-Sokkary, G.H., Kamel, E.S. and Reiter, R.J. 2003. Prophylactic effect of melatonin in reducing lead-induced neurotoxicity in the rat. Cell. Mol. Journal of Cellular \& Molecular Biology Letters, 8(2): 461470 .

Enb, A., Abou Donia, M.A., Abd Rabou, N.S., Abou-Arab, A.A.K. and El-Senaity, M.H. 2009. Chemical composition of raw milk and heavy metals behavior during processing of milk products. Journal of Global Veterinaria, 3(3): 268275.

EOSQ. 2012. Egyptian Organization for Standardization and Quality Control. Maximum level of heavy metals contaminant in food in food. ES 2360, Ministry of Industry. Cairo, Egypt.

Feng, M., Vander Does, L., Bantjes, A. and Groote, J.M.F.H. 1995 Iron Removal from Milk and Other Nutrient Media 
with a Chelating Resin. Journal of Dairy Science, 78(1): 55-61.

FDA (Food and Drug Administration). 2013. Dietary Reference Intakes for Vitamin A, Vitamin K, Arsenic, Boron, Chromium, Copper, Iodine, Iron, Manganese, Molybdenum, Nickel, Silicon, Vanadium, and Zinc. Report of the Panel on Micronutrients. National Academy Press, Washington, DC, Food and Drug Administration. Dietary supplements. Center for Food Safety and Applied Nutrition.

Fischer, W.J., Schilter, B., Tritscher, A.M. and Stadler, R.H. 2011. Environmental contaminants. Encyclopedia of Dairy Science, Academic press, London 2011, 1: 898 .

Foster, J.J. 2001. Data Analysis Using SPSS for Windows: A beginner's Guide (second edition) London Sage.

Ghafari, H.R. and Sobhanardakani, S. 2017. Contamination and health risks from heavy metals $(\mathrm{Cd}$ and $\mathrm{Pb})$ and trace elements $(\mathrm{Cu}$ and $\mathrm{Zn})$ in dairy products. Iranian Journal of Health Sciences, 5(3): 49-57.

Geise, G., M., Lee, H., S.; Miller, D., J., Freeman, B., D., McGrath, J., E. and Paul, D., R. 2010. Water purification by membranes: The role of polymer science. Journal of Polymer Science Part B: Polymer Physics, 48(15): 16851718.

Ghorbel-Abid, I., Galai, K. and Trabelsi-Ayadi, M. 2010. Retention of chromium (III) and cadmium (II) from aqueous solution by illitic clay as a low-cost adsorbent. Journal of Desalination, 256(2010): 190-195.
Giri S., Singh G., Jha, V.N. and Tripathi, R.M. 2011. Risk assessment due to ingestion of natural radionuclides and heavy metals in the milk samples: a case study from a proposed uranium mining area, Juurnal of Environmental Monitoring Assessment, 175(1-4): 157-166.

Gupta, V., Ali, I., Gupta, V. and Ali, I. 2013. Environmental Water: Advances in Treatment, Remediation and Recycling. Amsterdam, Heidelberg: Elsevier, 2991.

Ibrahim, E.M.A. 2004. Cadmium, copper and lead in some kinds of cheeses. Journal of Benha Veterinary Medicine, 15(2): $55-64$.

Ihedioha, J.N. and Okoye, C.O.B. 2012. Cadmium and lead levels in muscle and edible offal of cow reared in Nigeria. Journal of Bulletin Environmental Contamination and Toxicology, 88(3): 422-427.

Ismail, A., Riaz, M., Akhtar, S., Goodwill, J., E. and Sun, J. 2017. Heavy metals in milk: Global prevalence and health risk assessment. Toxin Reviews, 1-12.

Ismail, A., Riaz, M.; Akhtar, S.; Ismail, T.; Ahmad, Z. and Hashmi, M., S. 2015. Estimated daily intake and health risk of heavy metals by consumption of milk. Food Additives and Contaminants: Part B, 8 (4): 260-265.

Issa, S., Y., Genena, D.M., Al Mazroua, M.K., Abdel Rahman, S.M. and Fawzi, M.M. 2016. Determination of some metals in the commonly consumed dairy products randomly collected from the market in Alexandria-Egypt, with an emphasis on toxicity, permissible limits and risk assessment. International Journal of 
Pharmacology and Toxicology, 4(2): 133-137.

James, A. and Mcdougall, F., R. 1996. The treatment of toxic wastes. in: pollution (causes, effects and control), 3rd edition Harrison, R., M. Royal Society of chemistry, Cambridge, 123-143.

Javed, I., Jan, A., Muhammad, F., Rahman, Z., Zargham Khan, M., Aslam, B. and Iqbal, S. 2009. Heavy Metal Residues in the Milk of Cattle and Goats During Winter Season. Journal of Bulletin Environmental Contamination and Toxicology, 82(5): 616-620.

Kabir, A., Khan, K., Habib Khan, M.I., Jubair, T. and Jhahan, E. 2017. A study of heavy metal presence in cow milk of different dairy farms near Karnafuli paper mills, Chittagong, Bangladesh. American Journal of Engineering Research, 6(9): 329-333.

Kazi, T., G., Jalbani, N., Baig, J.A. Kandhro G.A., Afridi H.I., Arain M., B., Jamali, M.K. and Shah, A.Q. 2009. Assessment of toxic metals in raw and processed milk samples using electrothermal atomic absorption spectrophotometer. Journal of Food and Chemical Toxicology, 47(9): 2163-2169.

Khan, K., LU, Y., Ishtiaq, M., Khan, S., Waqas, M., Wei, L. and Wang, T. 2013. Heavy metals in agricultural soils and crops and their health risks in Swat District northern Pakistan. Journal of Food and Chemical Toxicology, 58: 449-458.

Khan, Z.I., Ahmad, K., Bayat, A., Mukhtar, M.K. and Sher, M. 2013. Evaluation of lead concentration in pasture and milk: A possible risk for livestock and public health. Pakistan Journal of Zoology, 45(1): 79-84.
Kim, D.G, Kim, M, Shin, J.Y., Son, S.W. 2016. Cadmium and lead in animal tissue (muscle, liver and kidney), cow milk and dairy products in Korea. Food Additives Contaminants: Part B. 9(1): 33-37.

Lante, A., Lomolino, G., Cagnin, M. and Spettoli, P. 2006. Content and characterization of minerals in milk and in Crescenza and Squacquerone Italian fresh cheeses by ICP-OES. Journal of Food Control, 17(3): 229-233.

Lasheen, M.R., El-Sherif, I.Y., El-Wakeel, S.T., Sabry, D.Y. and El-Shahat, M.F. 2017. Heavy metals removal from aqueous solution using magnetite Dowex 50WX4 resin nanocomposite. Journal of Materials and Environmental Science, 8(2): 503-511.

Leblanc J.C., Malmauret, L., Guérin, T., Bordet, F., Boursier, B. and Verger, P. 2000. Estimation of the dietary intake of pesticide residues, lead, cadmium, arsenic and radionuclides in France. Journal of Food Additives and Contaminants, 17(11): 925-932.

Licata, P., Di Bella, G., Potortì, A., Lo Turco, V., Salvo, A. and Dugo, G.M. 2012. Determination of trace elements in goat and bovine milk from Calabria (Italy) by ICP- AES. Food Additives and Contaminants: Part B Surveillance, 5(4): 268-71.

Madsen, H.T. 2014. Membrane filtration in water treatment - removal of micropollutants, in: Chemistry of advanced environmental purification processes of water - fundamentals and applications, Elsevier, The Netherlands, 199-248. 
Malhat, F., Hagag, M., Saber, A. and Fayz, A. 2012. Contamination of cow's milk by heavy metal in Egypt. Bulletin of Environmental Contamination and Toxicology, 88(4): 611-613.

Meshref, A.M.S., Moselhy, W.A., El-Houda, N. and Hassan, Y. 2014. Heavy metals and trace elements levels in milk and milk products. Journal of Food Measurement and Characterization, 8: 381-388.

Mitchell, E. 1981. Trace metal level in Queensland dairy products. Australian Journal of Dairy Technology, 36: 70-73.

Moreno-Rojas, R., Sánchez-Segarra, P.J., Cámara-Martos, F. and AmaroLópez, M.A. 2010. Heavy metal levels in Spanish cheeses: influence of manufacturing conditions. Food Additives and Contaminants: Part B, 3(2): 90-100.

Nasef, M.A. 2002. Heavy metal residues in milk and some dairy products in Damietta governorate and their public health significance. Zagazig, Egypt. Zagazig University, $\mathrm{PhD}$ thesis.

Nutrition Institute, Cairo, 2007. Daily consumption of adult person in Egypt. No. 43906. http://www.elharm .com/9134/INVES. HTM.

Pehlivan, E. and Altun, T. 2006. The study of various parameters affecting the ion exchange of $\mathrm{Cu} 2+, \mathrm{Zn} 2+, \mathrm{Ni} 2+, \mathrm{Cd} 2+$, and $\mathrm{Pb} 2+$ from aqueous solution on Dowex 50W synthetic resin. Journal of Hazardous Materials, 134(1-3): 149156.

Puls, R. 1994. Mineral levels in animal health: Diagnostic data (2nd edition). Sherpa International Clearbrook, BC.
Rahimi, E.2013. Lead and cadmium concentrations in goat, cow, sheep and buffalo milks from different regions of Iran. Journal of Food Chemistry, 136(2): 389-391.

ROHM and HAAS Company. 1997. Ion exchange resins, IMAC HP 333 (weak acid cation exchange resin), Philadelphia, U.S.A, ITS 0200A-April$2 / 2$.

Sherrington, D.C. 1998. Preparation, structure and morphology of polymer supports, Chemical Communications, 30(11): 2275-2286.

Solaiman, S.G., Maloney, M.A., Qureshi, G., Davis, G. and D'Andrea, G. 2001. Effects of high copper supplements on performance, health, plasma copper and enzymes in goats. Journal of Small Ruminant Research, 41(2): 127-139.

Temiz, H. and Soylu, A. 2012. Heavy metal concentrations in raw milk collected from different regions of Samsun, Turkey. International Journal of Dairy Technology, 65(4): 516-522.

Tsoumbaris, P. and Papadopoulou, T.H. 1994. Heavy metal in common food stuff: Quantitative analysis. Bulletin of Environmental Contamination and Toxicology 53(1): 61-66

USEPA, (US Environmental Protection Agency). 2000. Risk-based concentration table. United States Environmental Protection Agency, Washington DC, Philadelphia.

USEPA, (United States, Environmental Protection Agency), region 8, 2008. Baseline human health risk assessment for the standard mine site Gunnison County, Colorado. Syracuse Research Corporation. 
USEPA, (United States Environmental Protection Agency), 2014. Regional Screening Level (RSL) Summary Table.

WHO (World Health Organization) 2007. Health risks of heavy metals from longrange transboundary air pollution.

Yargeau, V. and Zeman, F. 2012. Understanding and Improving the Urban Environment, Elsevier. In Zeman F. Editor. Metropolitan Sustainability. Elsevier, 390-405.

Yu, M., Liu, Y., Achal, V., Fu, Q-L. and Li1, L. 2015. Health Risk Assessment of Al and Heavy Metals in Milk Products for Different Age Groups in China. Pol. Journal of Environmental Studies, 24(6): 2707-2714.

Zhuang, P., McBride, M.B., Xia, H., Li, N. and Li, Z. 2009. Health risk from heavy metals via consumption of food crops in the vicinity of Dabaoshan mine, south China. Journal of the Science of the Total Environment, 407(5): 1551-1561. 